Univerzitet u Beogradu
Poljoprivredni fakultet
Institut za poljoprivrednu tehniku
Naučni časopis
POLJOPRIVREDNA TEHNIKA
Godina XLIII
Broj 2, 2018.
Strane: $17-29$

\title{
DROPLET CHARACTERIZATION AND WATER DISTRIBUTION OF FIXED SPRAY PLATE SPRINKLER USED IN LINEARLY MOVED IRRIGATION SYSTEM
}

\author{
Ransford Opoku Darko*1, Shouqi Yuan', Junping Liu', Livingstone Sam-Amoah ${ }^{2}$ \\ ${ }^{1}$ Research Centre of Fluid Machinery Engineering and Technology, Jiangsu University, \\ Zhenjiang 212013, China \\ ${ }^{2}$ Department of Agricultural Engineering, University of Cape Coast, Central Region, \\ Cape Coast, PMB Ghana
}

\begin{abstract}
The irrigation uniformity of sprinkler irrigation system depends on many design factors such as nozzle diameter, operating pressure and riser height. An experimental study was conducted to investigate the effect of combination factors of operating pressure and riser height on water distribution and droplet diameter. To study the droplet characteristics of the fixed spray plate sprinkler (FSPS), droplet diameter and velocity were measured using a Thies Clima laser precipitation monitor. Statistical analysis was conducted on the drop size distribution using volume-weighted method. The volumetric cumulative frequency of drop diameters permitted to reconstruct water application along the sprinkler radius in term of the frequency of drops of different diameters with respect to elevation and working pressure. Wetted diameters and average application rates increased with the increase in pressure and nozzle elevation within a distance of less than $2 \mathrm{~m}$ from the sprinkler. The results showed that various combinations of the sprinkler could greatly change droplet and water distribution characteristics. Empirical equations for the water distribution from FSPS were also developed with coefficients of determination ranging from $95.0 \%$ to $99.6 \%$. The study concluded that the uniformity of a sprinkler irrigation system is more affected by the combination of distance from sprinkler, riser height and operating pressure.
\end{abstract}

Keywords: application rate, droplet diameter, hydraulic performance, sprinkler irrigation, water distribution.

\footnotetext{
${ }^{*}$ Corresponding author. E-mail adress: chiefrodarko@yahoo.com
} 


\section{INTRODUCTION}

Irrigation is a basic determinant of agriculture because its inadequacies are the most powerful constraints on the increase of agricultural production. Sprinkler irrigation remains one of the successful methods used by farmers to apply water to their crops. It is a planned system in which all necessary components have been installed for efficient application of irrigation water by means of sprayheads operated under pressure. The purpose of a sprinkler system is to efficiently and uniformly apply irrigation water to the crops or soil without causing erosion, excessive water loss, or reduction in water quality. It is necessary to evaluate the quality and efficiency of sprinkler irrigation system, including droplet size distribution and their influence on soil and crop growth. Designing and optimizing sprinkler irrigation systems is essentially based on achieving adequate hydraulic performance, which is significantly related to the droplet size and water distribution patterns [8], [16], [17], [23]. The characterization of drops resulting from fixed spray-plate sprinkler primarily implies the determination of their diameter as they approach the soil surface. Fine droplets of water travelling through the air have more evaporation losses rather than coarse droplets with respect to wind speed [9], [24]. Size distribution of the drops discharged by the water jet of an agricultural sprinkler has major influence on evaporation losses, modifying the infiltration capacity of the soil, and distortion of water distribution pattern applied by sprinkler [13], [15], [19], [25]. It is therefore of paramount interest to investigate drop size distribution over an irrigated area as its implication could affect the whole irrigation process.

Currently, linearly moved irrigation systems and center-pivot models are based on the overlapping of experimental sprinkler application pattern [20], [11]. According to [20], spray sprinklers which use low pressures are now been employed in linearly moved irrigation systems and centre pivots. The jet produced at the sprayhead immediately undergoes an inelastic shock as it frontally hits a plate. However, it appears that the drop formation begins at the surface of the jet and continues towards the centre [19], [27]. The upper limit lognormal distribution model was used to fit droplet size data which correlated with nozzle parameters and also ballistic models have been used to estimate the initial droplet size produced by a sprinkler. [13], [19], [28]. A third-order polynomial was used to describe the radial distribution [18] and [11] developed a model to simulate the application of water in a centre pivot irrigated field. From the above discussion it is evident that limited work has been done to compare the hydraulic parameters of FSPS on linearly moved irrigation system.

Hence the objective of this paper is to compare the effects of FSPS using different pressure regulator sprinklers at different height positions using a linearly moved irrigation system (LMIS) designed by the Research Centre of Fluid Machinery Engineering and Technology, Jiangsu University, China. This study focuses on comparing the hydraulic performance of the pressure regulator sprinklers introducing empirical equations for the water distribution and droplet diameter with respect to operating height and pressure. 


\section{MATERIALS AND METHODS}

The experiments were performed in an indoor laboratory of the Research Centre of Fluid Machinery Engineering and Technology, Jiangsu University, China. The experiment layout of the system is as shown in Fig. 1. The FSPS studied in this research was the Nelson D3000 sprayhead, with 36-grooved blue plate with a medium angle from the horizontal plane. Ouazaa et al. [21], reported that the water distribution of grooved deflector plates was similar to donut shaped patterns and can result in discrete streams with different throw distance. A $5.5 \mathrm{~mm}$ nozzle diameter of the FSPS was utilized during the experiment. The FSPS used was manufactured by Nelson Irrigation Corporation in Walla, Washington, USA (Fig. 2).
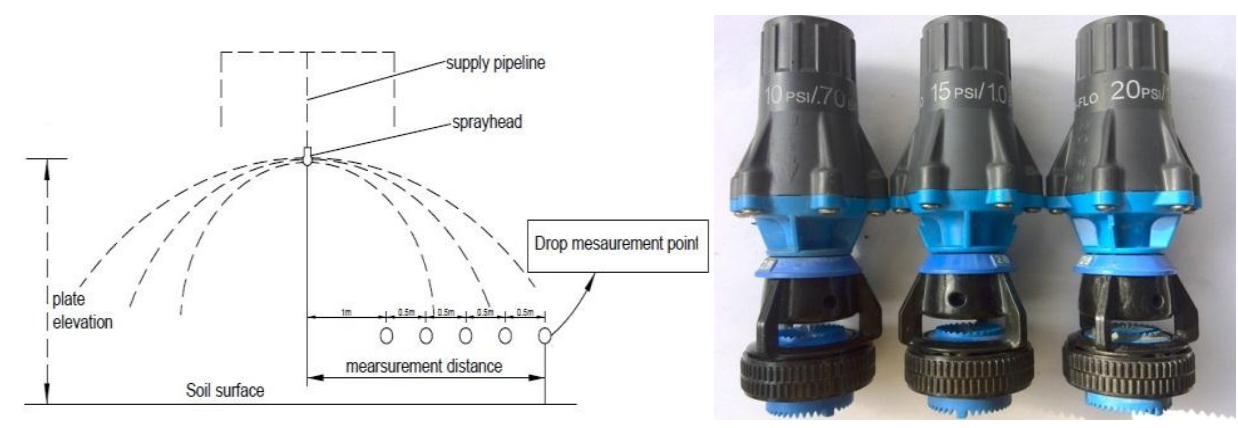

Figure 1. Experimental layout of the system

Figure 2. Fixed spray pressure heads used

The sprayheads were mounted on two different heights; h1-100cm and h2-150cm above the surface dependent on the experiment done for that occurrence and operated at working pressures of P1-10 psi, P2-15 psi and P3- 20 psi at different times during the experiment. A centrifugal pump was used to supply water to the irrigation system from a constant-level reservoir near the research laboratory. Thies Clima laser precipitation monitor (TCLPM) manufactured by Adolf Thies GmbH \& Co. KG, Goettingen, Germany was used to measure the sizes and velocities of the droplets emitted from the FSPS types selected for the experiments. The testing location for the TCLPM was set at $1 \mathrm{~m}$ from the FSPS for the initial reading followed by $0.5 \mathrm{~m}$ increment for successive readings. In the design of the experimental system, the following standards were taken into consideration to meet international standards: ASAE S.330.1. [1], ASAE S.398.1. [2], ISO7749-2. [12], and MOD GB/T 19795.2 (2005). The TCLPM is made up of with an imaging system composed of photodiode detector, laser transmitter and a storage circuit as shown in Figure 3. It is also connected to an analysis display system which assists in displaying data generated by the TCLPM. The TCLPM can accumulate the measured droplet diameter, calculate the application rate and hence the droplet spectra which contain the drop size range, the droplet velocity and corresponding particle number can be input in an excel file for further analysis. 


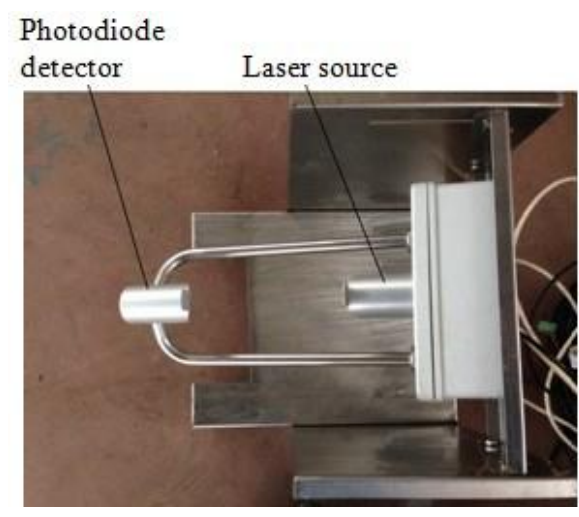

Figure 3. Structure of TCLPM

King et al. [15], described the test area of the TCLPM to be $23.0 \mathrm{~cm} \times 2.0 \mathrm{~cm}$ with the measurement range of particle diameter from $0.16 \mathrm{~mm}$ to $8.00 \mathrm{~mm}$. Bautista-Capetillo et al. [3], further postulated that TCLPM measured drop sizes $0.2 \mathrm{~mm}$ to $8.0 \mathrm{~mm}$. When using TCLPM, measurement errors caused by coincidence errors and edge effects cannot be eliminated. The edge effect errors occur when only a fraction of a droplet passes through the laser beam. When this phenomenon occurs, the laser detects a droplet that is smaller than its actual size. The average droplet diameter was represented to the drop size at different positions due to the changing droplet diameter in a comparatively large range. Currently, the methods used in calculating the average droplet diameter include the number average method, weighted average method and middle cumulative frequency diameter method. This article makes use of the realistic weighted average method to calculate the average size of droplets. Weighted average method means the ratio of corresponding weight of droplet diameters by different standard sieve meshes to the total weight of droplets at the sample location, using the following equation:

$$
\begin{gathered}
\bar{d}=\sum_{i=1}^{n} W_{i} d_{i} / \sum_{i=1}^{n} W_{i} \\
W_{i}=m_{i} \frac{\pi}{6} d_{i}^{3} \gamma_{w}
\end{gathered}
$$

where $\bar{d}_{\text {is }}$ the average size of droplets at sampling locations; ${ }^{d}{ }_{i}$ is drop diameter; $W_{i}$ refers to weight of water for droplet with diameter $d_{i} ; \gamma_{w}$ is the bulk density of water; $m_{i}$ is the number of droplet with diameter $d_{i}$ and $n$ corresponds to the types of droplet diameters. Data interpolation and representation of drop diameter, total volume and regression analysis were done using Microsoft Excel Program (2010). 


\section{EXPERIMENTAL RESULTS AND DISCUSSION}

\section{Water distribution pattern of FSPS}

For any combination of sprinkler nozzle elevation and working pressure, the water pattern distribution pattern was different for each experiment carried out. As an illustrative example of the individual water distribution pattern, Figure 4 presents the relationship between the application rate and distance from the sprinkler to LPM at h1 and $\mathrm{h} 2$ respectively for $\mathrm{P} 1, \mathrm{P} 2$ and $\mathrm{P} 3$.

Very large variability occurred in the radial direction. As a consequence, narrow wetted area resulted in large average precipitation and water droplets, which may lead to soil runoff losses and soil erosion [10] and [22, 23].

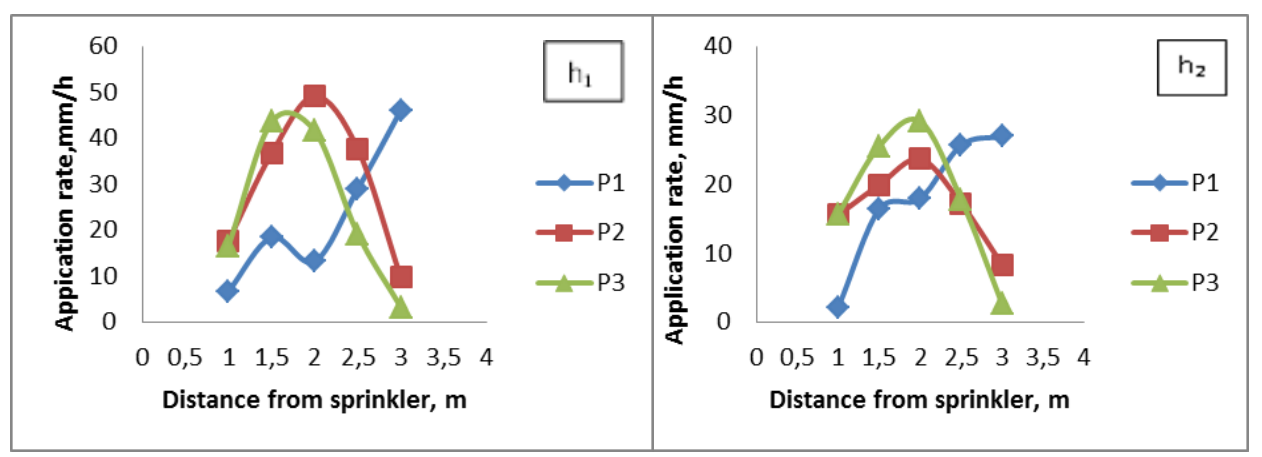

Figure 4. Water distribution pattern for FSPS at h1 and h2

Application rate found by the radial test as related to distance revealed that water distribution pattern curve under P1 for both height situations recorded water concentrated around and a distance away from the sprinklers due to probably unsatisfactory pressure. This is unlike that of the curves for P2 and P3 which showed that water from the FSPS settled around sprinkler due to fine drops caused by increased pressure. At P2 and P3 for the two different elevations used, the application patterns were evenly distributed along both sides of the sprinkler. With reference to h1, water distribution from P1 showed that the application rate was dropped from $19 \mathrm{~mm} / \mathrm{h}$ to $11 \mathrm{~mm} / \mathrm{h}$ at $2 \mathrm{~m}$ throw radius and rose to about $45 \mathrm{~mm} / \mathrm{h}$ at $3 \mathrm{~m}$ throw radius. This pattern was different to that of h2 however, at a throw distance of $2.5 \mathrm{~mm}$; the increase in application rate was marginal. Curves by P2 and P3 took a bell shape. Comparing the water distributions of $\mathrm{P} 2$ and $\mathrm{P} 3$ from the different elevations under the same condition, $\mathrm{h} 1$ produced a higher average application rate ranging from $0.5 \mathrm{~mm} / \mathrm{h}$ to $50.0 \mathrm{~mm} / \mathrm{h}$ than at $\mathrm{h} 2$ which also ranged from $0.4 \mathrm{~mm} / \mathrm{h}$ to $30 \mathrm{~mm} / \mathrm{h}$. This indicates that the variations in the water application rate are quite significant and P3 appears to have more uniformity in application rate than at P2 and P1. Although the operating conditions were controlled, they differed slightly between each measurement and the droplets measured on each occasion were different.

The working and hydraulic parameters of the different types of pressure regulators used at their specific elevations are as shown in Table 1. 
Table 1. Working and hydraulic parameters of the FSPS.

\begin{tabular}{lcc}
\hline Operating pressure level & $\begin{array}{c}\text { Nozzle diameter } \\
\mathbf{m m}\end{array}$ & Flow rate $\mathbf{m}^{3} / \mathbf{h}$ \\
\hline$P_{1}$ & 5.5 & 1.61 \\
$P_{2}$ & 5.5 & 1.79 \\
$P_{3}$ & 5.5 & 1.82 \\
\hline
\end{tabular}

Comparing the water distributions at the three operating pressure levels, P1 produced a lower application rate than at P2 and P3 for distance less than $2 \mathrm{~m}$ away from the sprinkler. Raising pressure from 10psi to 20psi generally increased the application rate at $\mathrm{h} 2$ at a distance less than $2.5 \mathrm{~m}$ away from the sprinkler. At $\mathrm{h} 1$ application rates at the different pressure level; P1, P2 and P3 were quite higher than at the elevation of h2. The differences can be attributed to the flow rate factor. Higher pressures increase flow along any pipe. As the flow increases, water velocity increases as well and as the water is rushing through the pipe, the interior walls of the pipe create friction against it which causes pressure loss thereby reducing the application rate. Hence it is important for irrigation system engineers to regulate the pressure at optimal levels to reduce such losses.

\section{Drop diameter values versus distance from FSPS}

Drop diameter distribution curves are presented in Figure 5 for all distances to the sprinkler. As the distance to sprinkler increases, the frequency of large drops increases. The smooth transition observed for distances up to $2.0 \mathrm{~m}$ becomes abrupt between distances of 2.0 and $3.0 \mathrm{~m}$ especially at h1. These differences could be attributed to the fact that drops landing at distances less than $2.0 \mathrm{~m}$ from the sprinkler can either be emitted from the nozzle or separate from the jet along its trajectory. This fact could explain the presence of drops with diameters less than $0.8 \mathrm{~mm}$, which completely disappear at a distance of $2.0 \mathrm{~m}$. From $2.0 \mathrm{~m}$ onwards, all drops seem to result from the disintegration of the jet, and the modal diameters are in the interval $2-7 \mathrm{~mm}$. This proposition was presented by [26] who reported similar results when analyzing drop diameter measurements of FSPS using a low speed digital photography method. 


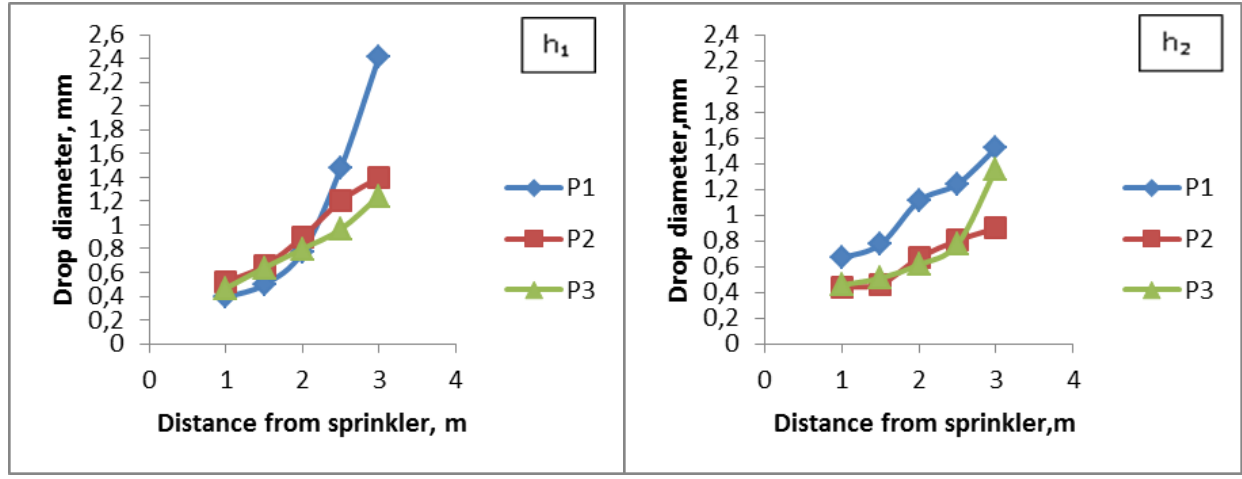

Figure 5. Drop diameter values versus distance from FSPS

The qualms associated with disdrometer measurements, evidenced by Burguete et al. (2007) raised some concern about the quantitative importance of these small drops. Photographic data confirmed the relevance of small drops at large distances from the sprinkler and pose further concerns about the adequacy of the sprinkler irrigation ballistic theory, specifically about the hypothesis stating that all drops are created at the nozzle.

Total volume and weighted cumulative frequency of droplet diameter along the range

Total volume of water applied for each pressure at given distances from the FSPS is presented in Figure 6 for different operating conditions. Three pressure regulators at h1 and h2 were employed in the experiments. As shown in Figure 6, generally, the total volume of the drops increased with increasing the distances from the sprinkler for both $\mathrm{h} 1$ and h2. This was however different in the case of operating pressure especially for P2 and P3 as the total volume of drops began to decrease at a distance of $2 \mathrm{~m}$ from the sprinkler position. This can be attributed to the differences in the frequency of the large drops. Total volume of drops at P1 kept increasing with increase in distance from the sprinkler for both $\mathrm{h} 1$ and $\mathrm{h} 2$. This indicates that although the number of large drops is low, their contribution with respect to volume is quite significant. The total volume distribution graphs indicate that the gradients of the total volume are greater when the droplets were near the sprinkler and their size was small. The results varied for higher distances from the sprinkler particularly at an elevation of $h 2$. 


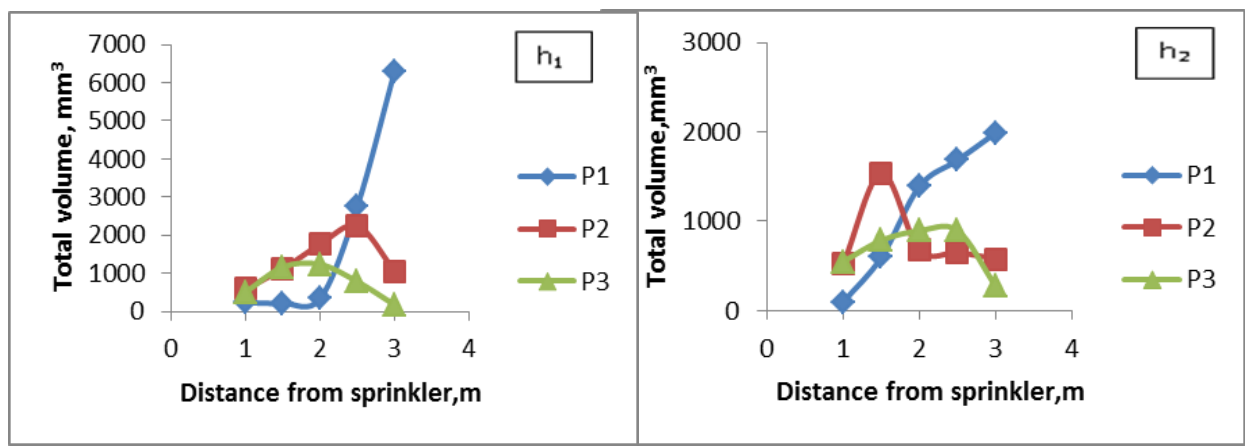

Figure 6. Total volume of water applied by each pressure as a function of distance to the sprinkler at h1 and $h 2$

These outcomes are in concurrence with those reported by other researchers [19], [25]. In this work, it may not be essential to operate at pressure level of P1 and at a riser height of $\mathrm{h} 1$ because using a combination of $\mathrm{P} 1 \mathrm{~h} 1$ results in increasing the total volume of applied water which will in the long run have an implication on cost and energy. Hence a combination of $\mathrm{P} 3 \mathrm{~h} 1$ and $\mathrm{P} 3 \mathrm{~h} 2$ will be considered more optimum when related with a normal distribution curve.

The weighted cumulative frequency means the cumulative value of specific gravity between the weighted which is less than one droplet diameter and the total weight of the spray. Figure 7 presents the weighted cumulative frequency of droplet diameters with different pressure regulators at two different height positions above the ground surface. As shown below, the weighted cumulative frequency of droplet diameters with different pressure regulators are different. With an increase in distance, the weighted cumulative frequency which is less than one droplet diameter will decrease and the slope of weighted cumulative frequency increases with the increase in the range distance. These results are in conformity with those reported by other researchers [25] and [19]. 


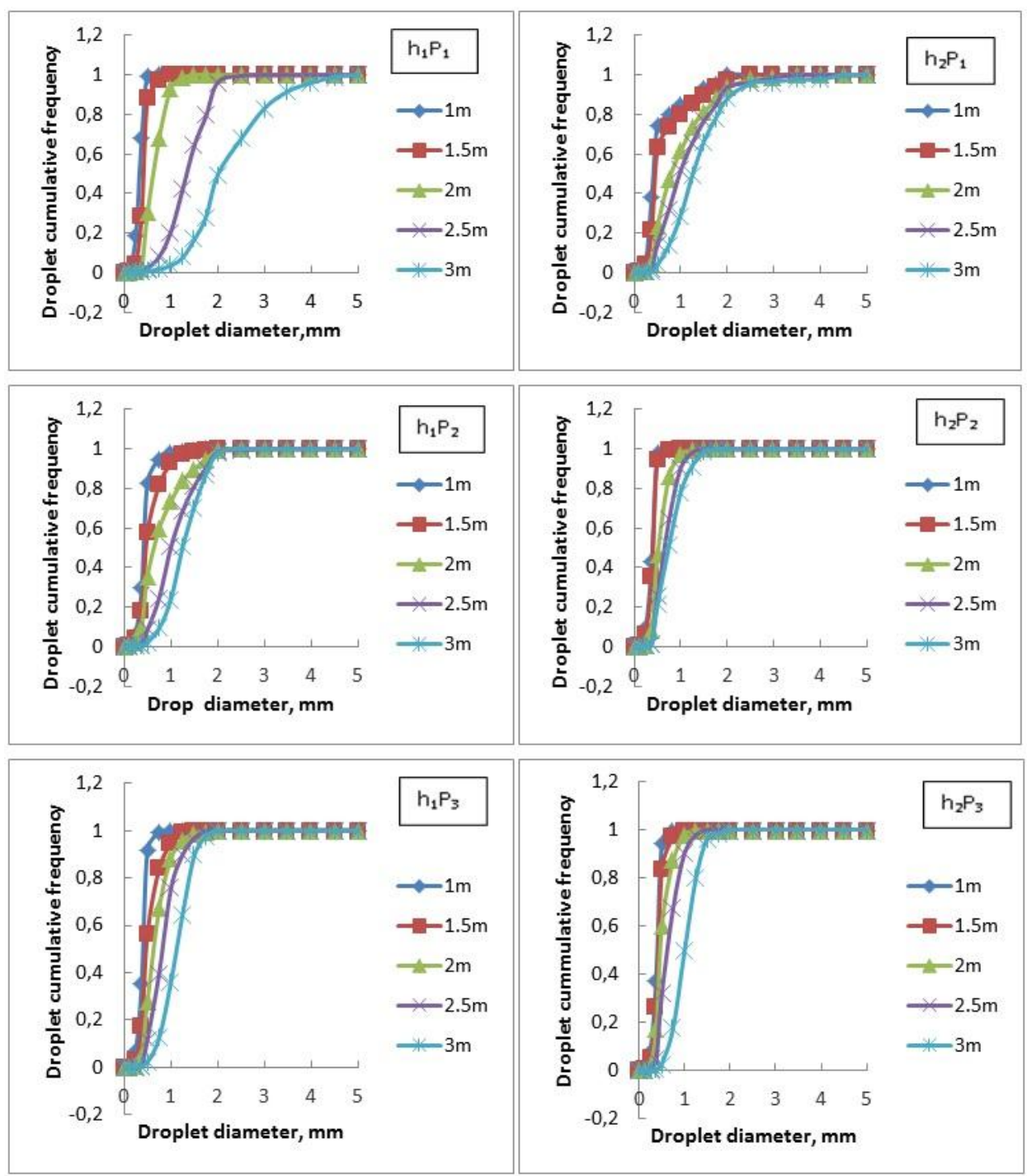

Figure 7. Curves of cumulative frequency of droplet diameter using different pressure regulators at different elevations.

Besides increasing drop size with increasing operating pressure, an increase in the range of drop diameters can be seen in Figure 7 above. The drops deposited at each observed distance were not of the same diameter but varied. This phenomenon may have two major causes. First, the minimum values of the droplet diameter are almost the same for all evaluated conditions but their maximum values differ in accordance with sprinkler working conditions. This entails that, at any rate of the sprinkler working conditions, some fine droplets fall at distances near to the sprinkler where the amount of applied water is very low. 


\section{Establishment of a mathematical Model for FSPS}

Special attention was given to the development of empirical equations for the water distribution model regarding the distance traveled from the FSPSs. A third -order polynomial regression line to describe the radial presented in Table 2 was drawn to the distance from the sprinkler and the application rate data to estimate the water distribution where $\mathrm{y}$ is the application rate and $\mathrm{x}$ is the distance from the sprinkler. The coefficient for determination of FSPS ranged from $95.0 \%$ to $99.6 \%$, with an average of $97.6 \%$. The range is in agreement with the findings of [17] who postulated the coefficient of determination for PXH sprinkler as ranging from $95.1 \%$ to $98.8 \%$.

Table 2 Regression analysis with third-order polynomial.

\begin{tabular}{cccc}
\hline $\begin{array}{c}\text { Operating } \\
\text { pressure level }\end{array}$ & $\begin{array}{c}\text { Riser } \\
\text { height level }\end{array}$ & Third-order polynomial & $\begin{array}{c}\text { Coefficient of } \\
\text { determination } \\
(\%)\end{array}$ \\
\hline$P_{I}$ & $h_{1}$ & $y=12.137 x^{3}-637 x^{2}+116.72 x-57.35$ & 95.0 \\
& $h_{2}$ & $y=4.16 x^{3}-30.377 x^{2}+80.412 x-51.498$ & 96.3 \\
$P_{2}$ & $h_{1}$ & $y=6.6007 x^{3}-5.8857 x^{2}+58.259 x-40.254$ & 99.1 \\
& $h_{2}$ & $y=-1.1767 x^{3}-3.4271 x^{2}+25.406 x-5.5418$ & 96.7 \\
$P_{3}$ & $h_{1}$ & $y=23.617 x^{3}-172.05 x^{2}+374.52 x-209.79$ & 99.6 \\
& $h_{2}$ & $y=1.5833 x^{3}-28.045 x^{2}+85.071 x-43.219$ & 98.6 \\
\hline
\end{tabular}

Research on the variation trend of the droplet diameter was carried out using the linear theory and the experimental correlation of droplet diameters is concluded in Equations 3 and 4. Comparing the results with experimental data, the accuracy error was less than $4 \%$ and the analysis of droplet diameters was accurate. According to these equations, the distances from the sprinkler and the working pressure have influences on the end droplet diameter of the sprinkler at the two elevations used in this research and changing the trend as a nonlinear equation.

$$
\begin{aligned}
& \mathrm{h}_{1}: d=1.707 L^{1.549} p^{-0.6539} \\
& \mathrm{~h}_{2}: d=2.226 L^{0.8918} p^{-0.6101}
\end{aligned}
$$

where $\mathrm{d}$ is the drop diameter, $\mathrm{mm}$; $\mathrm{L}$ is distance from sprinkler, $\mathrm{m}$ and $\mathrm{p}$ is working pressure, psi.

\section{CONCLUSION}

The size distribution of the droplets discharged by the water jet of a sprinkler is very important as this can explain several processes related to water distribution. Individual water distribution pattern and discharge-pressure relation of D3000 sprayhead at the designed working pressures and nozzle elevations were of importance in designing the LMIS and to evaluate the quality of water distribution. An indoor experiment was conducted to obtain droplet size distribution and radial application patterns of D3000 sprayhead sprinkler fitted at different and working pressures. 
The volumetric cumulative frequency of drop diameters permitted to reconstruct water application along the sprinkler radius in term of the frequency of drops of different diameters with respect to elevation and working pressure. As a result, wetted diameters and average application rates increased with the increase in pressure and nozzle elevation within a distance of less than $2 \mathrm{~m}$ from the sprinkler. The results showed that various arrangements of the sprinkler could greatly change droplet and water distribution characteristics. Empirical equations for the water distribution from FSPS were also developed with coefficients of determination ranging from $95.0 \%$ to $99.6 \%$. These relationships could enable designers to properly analyze the water distribution patterns produced by an FSPS. The study concluded that the irrigation uniformity of a sprinkler irrigation system is more affected by the combination of distance from sprinkler, riser height and operating pressure.

\section{ACKNOWLEDGMENTS}

We greatly appreciate the careful and precise reviews by the anonymous reviewers and editors.The National key research and development program No.2016YFC0400202, the key teacher training project of Jiangsu University and the Priority Academic Program Development of Jiangsu Higher Education Institutions (PAPD).

\section{REFERENCES}

[1] ASAE Standards (1985a). Procedure for sprinkler distribution testing for research purposes (32nd ed). St. Joseph, Mich: ASAE. S330.1

[2] ASAE Standards (1985b). Procedure for sprinkler testing and performance reporting (32nd ed.). St. Joseph, Mich: ASABE. S398.1.

[3] Bautista-Capetillo, C. F., R. Salvador, J. Burguete, J. Montero, J.M. Tarjurlo, N. Zapata et al. (2009). Comparing methodologies for the characterization of water drops emitted by an irrigation sprinkler. Transactions of the ASAE. 52; 1493-1504.

[4] Bautista-Capetillo, C., M. Zavala and E Playán (2012). Kinetic energy in sprinkler irrigation: different sources of drop diameter and velocity. Irrigation Science. 30(1); 29-41.

[5] Bautista-Capetillo, C., O. Robles, H. Salinas and E. Playán (2014). A particle tracking velocimetry technique for drop characterization in agricultural sprinklers. Irrigation Sci. 32: 437-447.

[6] Burguete, J., E. Playán, J. Montero and N. Zapata (2007). Improving drop size and velocity estimates of an optical disdrometer: Implications for sprinkler irrigation simulation. Trans Am Soc Agric Biol Eng. 50(6); 2103-2116.

[7] Carrion, P., J.M. Tarjuelo and J. Montero (2001). SIRIAS: a simulation model for sprinkler irrigation: I Description of the model. Irrigation Sci. 2001(20); 73-84.

[8] Chen, D and W.W. Wallender (1985). Droplet size distribution and water application with low-pressure sprinklers. Transactions of the ASAE. 28: 511-516.

[9] DeBoer, D. W. (2002). Drop and energy characteristics of a rotating spray-plate sprinkler. Journal of Irrigation and Drainage Engineering. 128:137-146.

[10] DeBoer, D. W. and M. J. Monnens (2001). Estimation of drop size and kinetic energy from a rotating-plate sprinkler. Transactions of the ASAE. 44: 1571-1580. 
[11] Delirhasannia, R., A.A. Sadraddini, A.H. Nazemi, D. Farsadizadeh and E. Playán (2010). Dynamic model for water application using centre pivot irrigation. Biosyst Eng. 105:476485.

[12] ISO, 7749 - 2. 1990. MOD, GB/T 19795.2. 2005. Agricultural irrigation equipment-rotating sprinklers-part 2: Uniformity of distribution and test methods. International Standards Organization.

[13] Kincaid, D. C., K.H. Solomon and J.C. Oliphant (1996). Drop size distributions for irrigation sprinklers. Transactions of the ASAE. 39(3); 839-845.

[14] Kincaid, D. C. (1996). Spray drop kinetic energy from irrigation sprinklers. Transactions of the ASAE. 39(3); 847-853.

[15] King, B. A., T.W. Winward and D.L. Bjorneberg (2010). Laser precipitation monitor for measurement of drop size and velocity of spray-plate sprinklers. Applied Engineering in Agriculture. 26: 263-271.

[16] Li, J., and H. Kawano (1996). Sprinkler rotation non uniformity and water distribution. Transactions of the ASAE. 39; 2027-2031.

[17] Li, J., H. Kawano and K. Yu (1994). Droplet size distributions from different shaped sprinkler nozzles. Transactions of the ASAE. 37; 1871-1878.

[18] Liu, J., S. Yuan and R.O. Darko (2016). Characteristics of water and droplet size distribution from fluidic sprinklers. Irrig. and Drain. 65: 522-529.

[19] Montero, J., J.M. Tarjuelo and P. Carrion (2003). Sprinkler droplet size distribution measured with an optical spectro-pluviometer. Irrigation Sci. 22(2); 47-56.

[20] Omary, M. and H. Sumner (2001). Modeling water distribution for irrigation machine with small spray nozzles. J Irrig Drain Eng. 127(3); 156-160.

[21] Ouazaa, S., J. Burguette, P.M. Panigua, et al. (2014). Simulating water distribution patterns for fixed plate sprinkler using the ballistic theory. Spanish Journal of Agricultural Research. 12(3); 850-863.

[22] Playán, E., N. Zapata, J. Burguete, R. Salvador and A. Serreta (2010). Application of a topographic 3D scanner to irrigation research. Irrigation Sci. 28(3); 245-256.

[23] Playán, E., S. Garrido, J.M. Faci et al. (2004). Characterizing pivot sprinklers using an experimental irrigation machine. Agr Water Manage. 70: 177-193.

[24] Sadeghi, S. H., T.R. Peters, M. Z. Amini, S.L. Malone and H.W. Loescher (2015). Novel approach to evaluate the dynamic variation of wind drift and evaporation losses under moving irrigation systems. Biosystems Eng. 135(7); 44-53.

[25] Salvador, R., C. Bautista-Capetillo, J. Burguete, N. Zapata N, A. Serreta and E. Playán. (2009). A photographic methodology for drop characterization in agricultural sprinklers. Irrigation Sci. 27: 307-317.

[26] Sayyadi, H., A.H. Nazemi, A.A. Sadraddini and R. Delirhasannia (2014). Characterising droplets and precipitation profiles of fixed spray-plate sprinkler. Biosyst Eng. 119:13-24.

[27] Seginer, I., D. Nir and R.D von Bernuth (1991). Simulation of wind-distorted sprinkler patterns. Journal of Irrigation and Drainage Eng. 117(2); 285-306.

[28] Solomon, K. H., D.C. Kincaid and J.C. Bezdek (1985). Drop size distributions for irrigation spray nozzles. Transactions of the ASAE. 28; 1966-1974.

[29] Vories, E. D., R.D. von Bernuth and R.H. Mickelson (1987). Simulating sprinkler performance in wind. Journal of Irrigation and Drainage Engineering. 113(1); 119-130.

[30] von Bernuth, R. D. and J.R. Gilley (1984). Sprinkler droplet size distribution estimation from single leg test data. Transactions of the ASAE. 27(5); 1435-1441. 


\title{
KARAKTERIZACIJA KAPLJICA I DISTRIBUCIJE VODE FIKSNOG RASPRSKIVAČA KOJI SE KORISTI U SISTEMU NAVODNJAVANJA LINEARNOG TIPA
}

\author{
Ransford Opoku Darko ${ }^{* 1}$, Shouqi Yuan ${ }^{1}$, Junping Liu ${ }^{1}$, Livingstone Sam-Amoah ${ }^{2}$ \\ ${ }^{I}$ Research Centre of Fluid Machinery Engineering and Technology, Jiangsu University, \\ Zhenjiang 212013, China \\ 2 Department of Agricultural Engineering, University of Cape Coast, Central Region, \\ Cape Coast, PMB Ghana
}

\begin{abstract}
Ujednačenost sistema navodnjavanja sa rasprskivačima zavisi od mnogih faktora projektovanja, kao što su: prečnik mlaznice, radni pritisak i visina postolja. Sprovedena je eksperimentalna studija kako bi se ispitao uticaj kombinacije faktora radnog pritiska i visine postolja na raspodelu vode po površini i prečnik kapljice. Da bi se proučile karakteristike kapljice fiksnog rasprskivača tipa FSPS, prečnik i brzina kapljica su mereni pomoću laserskog monitora tipa Thies Clima.

Statistička analiza je urađena za raspodelu veličine kapi korišćenjem ponderisanog modela, metoda odnos zapremina-težina. Kumulativna zapremina učestalosti prečnika pada kapljica urađena je u odnosu na radijus rasprskivača u smislu učestalosti kapljica različitih prečnika u odnosu na visinu postolja i radni pritisak. Prečnici vlažene površine i prosečne brzine kapljica su registrovane kod povećanja pritiska i mlaznice na udaljenosti manjoj od $2 \mathrm{~m}$ od rasprskivača.

Rezultati su pokazali da promene kombinacije rasprskivača mogu značajno promeniti karakteristike kapljice i raspodelu vode. Empirijske jednačine za distribuciju vode iz programa FSPS su razvijene sa koeficijentima određivanja u rangu od 95,0\% do $99,6 \%$.

Studija ima zaključak da je ujednačenost sistema navodnjavanja sa rasprskivačima najviše zavisi od kombinacije udaljenosti rasprskivača, visine postolja i radnog pritiska vode u sistemu .
\end{abstract}

Ključne reči: norma navodnjavanja, prečnik kapljice, hidraulične performanse, navodnjavanje rasprskivačem, distribucija vode.

Prijavljen:

Submitted:

Ispravljen:

Revised:

Prihvaćen:

Accepted:

10.03.2018.

20.04.2018

07.07.2018.

\footnotetext{
*Kontakt autor. E-mail adress: chiefrodarko@ yahoo.com
} 